\title{
DOI: 10.7596/taksad.v8i3.1987
}

Citation: Koruroğlu, A. (2019). Postmodern Yaklaşımın Tarih Eğitimine Yansımaları. Journal of History Culture and Art Research, 8(3), 452-464. doi:http://dx.doi.org/10.7596/taksad.v8i3.1987

\section{Postmodern Yaklaşımın Tarih Eğitimine Yansımaları}

\author{
Reflections of Postmodern Approach to History Education
}

\begin{abstract}
Ayten Koruroğlu ${ }^{1}$
Abstract

Postmodernism is characterized as a concept following the modernity and it is referred together with the concepts of deconstructionism or post-structuralism. Postmodernism, which is used in the meaning of the future of modernism, has an attitude against modernism. Today, the debate on postmodernism and modernism has not ended yet. Postmodernists see the world as a pattern which is alterable and diverse. The concept of postmodern history is against the traditional concept of history. As the postmodernism gives importance to popular culture, it argues that it is necessary to use local and oral history methods in the writing of history. Persons and groups who have not entered the history textbooks should be studied, the events that are important to the local community should be examined and discussed, and daily life should be addressed. Postmodernism places importance on localism and local culture. In this context, postmodernism considers verbal history as the most appropriate approach to the study of local history.

The purpose of this research is to explain the reflections of postmodern education in history education. The research is a study in documentary screening type. For the collection of research data, research related to the subject were used. In this research, the concept of postmodernism is tried to be explained and the effects of this concept on education, especially history education, are discussed. As a result of the nature of postmodernism, it has brought a new perspective to traditional history and history education. Although this perspective has been widely accepted by traditionalist historians, it has been adopted by many innovative historians, because of the new approaches in education. Especially constructivism, the reflection of the postmodernist approach, is a widely accepted conception today. In this context, understanding postmodernism as a concept and studying its reflections on history education are the main purpose in this research. The concept of postmodern history is seen as an understanding of local and verbal history. Therefore, in this research, the concepts of local and verbal history have been tried to be explained by also using the literature review.
\end{abstract}

Keywords: Postmodernism, Postmodern History, History Education, Local History, Oral History.

\footnotetext{
${ }^{1}$ Yrd. Doç. Dr., Yakın Doğu Üniversitesi, Fen Edebiyat Fakültesi, Tarih Bölümü, Lefkoşa, KKTC. E-mail: ayten.koruroglu@neu.edu.tr
} 


\section{Öz}

Postmodernizm, modern sonrası olarak nitelendirilmekte, yapıbozumculuk veya postyapısalcılık kavramlarıyla birlikte anılmaktadır. Modernin ilerisinde anlamında kullanılan postmodernizim, modernizme karşı bir tavır sergilemektedir. Bugün halen postmodernizm ve modernizm tartışmaları son bulmuş değildir. Postmodernistler dünyayı değiş̧ebilir ve çeşitli bir desen olarak görmektedirler. Postmodern tarih anlayışı ise, geleneksel tarih anlayışına karşıdır. Postmodernizm popüler kültüre önem verdiği için, tarih yazımında yerel ve sözlü tarih yöntemlerinden yararlanılması gerektiğini savunmaktadır. Tarih ders kitaplarına girmemiş kişi ve gruplar araştırılmalı, yerel toplumca önemli görülen olaylar incelenip ele alınmalı, gündelik hayat işlenmelidir. Postmodernizm yerelliğe ve yerel kültüre önem vermektedir. Bu bağlamda postmodernizm yerel tarihin incelenmesine en uygun yaklaşım olarak sözlü tarihi görmektedir.

Araştırmanın amacı postmodern eğitim anlayışının tarih eğitimindeki yansımaları açıklamaktır. Araştırma, belgesel tarama türünde bir çalışmadır. Araştırma verilerinin toplanması için konu ile ilgili araştırmalar harmanlanarak kullanılmıştır. Yapılan araştırmada öncelikle postmodernizim kavramı açıklanmaya çalışılmış olup bu kavramın eğitime özellikle tarih eğitimine etkileri tartışılmıştır. Postmodernizmin doğası gereği her alana yenilik getirmiş olduğu gibi geleneksel tarih anlayışına ve tarih eğitimine de farklı bir bakış açısı getirmiştir. Bu bakış açısı gelenekselci tarihçiler tarafından pek kabul görmese de günümüzde eğitimdeki yeni yaklaşımlar dolayısı ile pek çok yenilikçi tarihçi tarafından da benimsenmiştir. Özellikle postmodern yaklaşımın yansıması yapılandırmacılık günümüzde çok kabul gören bir anlayış durumundadır. Bu bağlamda bu çalışmada kavram olarak postmodernizimi anlamak ve özellikle tarih eğitmine yansımalarını incelemek ana hedef olmuştur. Postmodern tarih anlayışı ise karşımıza yerel ve sözlü tarih anlayışı olarak karşımıza çıkmaktadır. Bu nedenle yapılan araştırmada yerel ve sözlü tarih kavramları da kaynak taraması yapılarak açıklanmaya çalışılmıştır.

Anahtar Kelimeler: Postmodernizm, Postmodern Tarih, Tarih Eğitimi, Yerel Tarih, Sözlü Tarih.

\section{Giriş}

Postmodern, postmodernizm kavramı birçok farklı anlamlar almakta ve halen daha kavramın ne olduğu ile ilgili farklı görüşler ortaya atılmaktadır. Lyotard, Jencks, Jenkins, Hollinger gibi postmodernizmin önde gelen savunucuları da bu kavrama farklı tanımlamalar yapmıştır. Bütün bu kavram karmaşasının yaşanmasının bir nedeni de aslında postmoderniteyi savunan bu düşünürlerin bu kavramı çeşitli formlarda açıklamış olmalarından kaynaklanmaktadır. Basit bir anlatıyla açıklamak gerekirse Postmodernizm; modernizme eleştiri olarak ortaya çıkan, modernizm sonrası olarak ifade edilebilir. Bu tanımdan hareketle postmodernizm, modernizmin bir üst aşaması, sanayi sonrası toplumu ifade eden kavram olarak tanımlanabilir. Postmodernizmin, modernizmle birlikte açıklanmasının nedeni ise postmodernizmin modernizme bir eleştiri olarak çıkmasından dolayıdır (Akpınar, Çakmak \& 
Kara, 2010; Aksoy, 2010; Aydın, 2006; Doltaş, 2003; Hollinger, 2005; Jencks, 2010; K1lıç \& Bayram, 2014; Lyotard, 2000; Sarup, 2004, Koruroğlu \& Özkul, 2017).

Postmodernizm bilgi çağının gelişmesi ile her alanda tartışmalara neden olduğu gibi eğitim alanında da tartışmalara ve yeni yaklaşımlara neden olmuştur. Postmodernizmin eğitimdeki uzantısı yapılandırmacı yaklaşım olarak karşımıza çıkmaktadır. Özellikle Türkiye'de 2004 yılında, Milli Eğitim Bakanlığının eğitim programlarında yaptığı yenilikçi değişimler, postmodernizmin kavramının adı geçmeden ilköğretim programlarına yapılandırmacılık olarak yansıyan şeklidir (Akpınar, vd., 2010; Kılıç\& Bayram, 2014, Koruroğlu \& Özkul, 2017).

$\mathrm{Bu}$ doğrultuda postmodern modele göre eğitim programları çağdaş ve yenilikçi olmalıdır. Bu modelde bilgi özneldir, çocuk öznedir. Öğrenme, öz olarak öğrencinin var olan bilgisi temelinde deneyimlerini yeniden yapılandırılmasını içermektedir. Öğrenme, öz olarak öğrencinin var olan bilgisi temelinde deneyimlerini yeniden yapılandırılmasını içermektedir. $\mathrm{Bu}$ noktada eğitimin başarısı çocuğun başlangıç noktasıyla, daha sonra ulaştığı gelişim düzeyindeki farkın ölçülmesine bağlıdır. Postmodernizm şu anda dünya anlayışı ile ilerlemekte ve çoğulculuk özelliğini taşımaktadır. Ayrıca postmodernizmin eklektik yani derleyen bir yapısı vardır. Postmodernizmin diğer bir özelliği ise Jencks (2010) tarafından dikkat çekilen çok tabakalı yorumlama kavramıdır. Jencks, postmodernizmin geçmişe baktığını hatta geçmişin ötesine geçtiğini belirtmekte, geleceğin geçmişin üstüne kurulduğunu ve geçmişin bir dönüşümü olduğunu söylemektedir (Aydın, 2006; Jencks, 2010).

Postmodern yaklaşım her alana etki etmiştir. Tarih, tarih eğitimi ve öğretimi de postmodernizmin etkilediği alanlardandır. Çoğu tarihçi tarafından eleştirilen postmodern tarih algıs1, tüm eleştirilere ve kabullenmemelere rağmen tarih eğitimine ve öğretimine yeni bir bakış açısı getirdiği muhakkaktır. Gelenekselci tarihçiler postmodernizmi büyük tehlike olarak görmektedirler. Bunun nedeni ise postmodernizmin tarihte birçok tabuyu yıkmasıdır. En önemli postmodern tarih savunucuları olarak, K. Jenkins, G. G. Iggers, F.R. Ankersmit, H. Kellner, R. F. Berkhofer, S. Opperman, D. LaCapra, D. Harlan, D.D. Roberts, B.Southgate, A.Munslow ve P. Joyce sayllabilir (Iggers, 2003; Keskin, 2008; Opperman, 2006; Parkers, 2006 ; Y1lmaz; 2013).

\section{Tarih Eğitimi ve Postmodernizm}

Geleneksel tarih anlayışına sahip tarihçiler, postmodernizmi bir tarihin sonunu getiren katile benzetmektedirler. Durum onların perspektifinden değerlendirildiği zaman bu düşüncelerinde pek de haksız sayılmazlar. Çünkü postmodernizm, geleneksel tarihin bütün tabularını yıkmaktadır. Postmodernist anlayışa göre gerçek bilgi yoktur. $\mathrm{Bu}$ anlayış çerçevesinde tarih de geçmişin üzerine yorumlamaların yapılması ile oluşturulmuş özellikle dilin etkili olduğu bir söylemdir. Postmodernistler, tarihin objektif değil subjektif olduğu görüşünü savunmaktadırlar (Iggers, 2000; Jenkins, 1997; Yılmaz, 2013).

Postmodern yaklaşım, tarih yazımında kullanılan kaynakları ve tarihçinin rolünü eleştirir. Tarih yazımında dil ve dilin kullanımının yorumun önemli olduğunu vurgular. Tarihin betimsel bir yapı içerisinde anlamlandırma ile önem kazanan bir edebi ürün olduğunu 
iddia eder. Aslında geçmiş ile ilgili elde edilen kaynaklara ve arşive belgelerinin tarihçilerin yorumu olduğuna işaret eder. $\mathrm{Bu}$ nedenle postmodern kuram tarihin ortaya çıkış noktasını hedef almıştır. Tarih bilgisinin oluşturulmasında ve geçmişin açıklanmasında modernist tarihçilerin kullandığı gerçeklik kavramını yok saymıştır. Bu açıdan bakıldığı zaman postmodernizm, tarihçiler tarafından, modern tarih anlayışına bir tehdit olarak görülmektedir (Coleman, 2013; Iggers, 2000; Jenkins,1997; Southgate, 2012; Y1lmaz, 2013).

Postmodern tarih öğretiminde öncelikle tarihsel bilginin anlaşılması için tarihsel bilginin doğasının ve dilinin tarihin inşaa edilmesinde kullanılmasının öneminin öğrencilere aktarılması gerekmektedir. Bu nedenle tarih öğretiminde tarih felsefesi ve tarih metodolojisi gibi dersler programda yer almalıdır (Harvey, 2003; Jenkins, 1997; Lyotard, 2000).

Okullarda tarih öğretimi yapılırken, tarih yazımındaki ve öğretimindeki yeni yaklaşımlar tartışılmalı. Öğrenciler bu yaklaşımlarla ilgili düşünmeye yöneltilmeli, farklı ideolojilere sahip profesyonel tarihçilerin eserleri irdelenerek eleştirilmelidir. Postmodern tarih kuramı tarih dersi öğretilirken tek bir yoruma yer verilmemelidir. Öğrencilere, tarafsız bir tarih görüşü olmadığı düşüncesinden yola çıkılarak, resmi tarih dahil, hiçbir tarihsel yorumun yansız olmadığı anlatılmalı ve tarihi bu bakış açısıyla değerlendirmeleri sağlanmalıdır (İggers, 2000; Jenkins, 1997; Southgate, 2012).

Postmodern tarih anlayışına göre tarihsel bilgi, tarihçilerin yorumlamalarına dayanan bir söylem olduğu için, tarih eğitimi sınıfta yapılırken, tarihin kesinleşmiş bir yargıya ulaştığ1 şeklinde açıklamalar yapılmamalı ve bunun yerine tarihin farklı yorumlamalara açık olduğu görüşünden yola çıkılmalıdır (Boboc, 2012; Iggers, 2000; Jenkins, 1997; Southgate, 2012).

Öğrencilerin tarihi algılamalarında ve yorumlamalarında farklı bir perspektif kazandırılacak şekilde tarih öğretimi yapılmalıdır. Ezbere dayalı değil, öğrencilerin geçmişe bakış açılarında ve tarihsel olayları ele alış biçimlerinde değişim yapmayı ve anlayışlarını geliştirmeyi, kısaca tarih öğrenmelerinde kişisel dönüşümü hedefleyen bir tarih öğretimi yapılmalıdır (Boboc, 2012; Coleman, 2013; Hart, 2007; Y1lmaz, 2013).

Postmodernizm davranışçı yaklaşımı ve bu yaklaşıma dayalı yöntemlerin sınıfta uygulanmasını eleştirmektedir. Tarih dersinin öğrenciler tarafından ezbere dayanan, kişi, yer ve tarih adlarının ezberlendiği bir ders olarak algılandığı herkes tarafından bilinen bir gerçektir. Bu nedenle tarih öğretimi planlanırken öğretmen merkezli ve ders kitabı odaklı öğretim yaklaşımı terk edilmelidir. Bunun yerine öğrencilerin kendi doğru bilgilerine ve tarih algılarına ulaşmalarını sağlamak için, diyalog temelli, sokratik diyalog, buluş yoluyla öğrenme, probleme dayalı öğrenme gibi yaklaşımlar sınıflarda uygulanmalıdır (Boboc, 2012; Coleman, 2013; Jenkins, 1997).

Postmodern tarih eğitimi anlayışında, kronolojik bir tarih öğretimi değil tematik temelli, diyalog temelli ve yorumsamacı bir tarih anlayışı benimsenmelidir. Postmodern tarih anlayışı herhangibir kişi, kurum, devlet yada bölgeyi merkezine almadığı için, tarih öğretimi yapılırken, ne Avrupa, ne Amerika, ne İslam, ne de daha farklı merkezli bir tarih anlayışı benimsenmelidir. Postmodernizm tarih anlayışında herhangi bir kişi ya da ideoloji merkeze alınmamalıdır. Bu nedenle postmodern tarih anlayışına göre Atatürk İlkeleri ve İnkılap tarihi 
dersi olmamalı, bunun yerine Cumhuriyet tarihi dersi olmalıdır. Liberal muhafazakar, sosyalist, milliyetçi, sağ ve sol farklı görüşlerdeki tarihçilere yer verilmeli ve öğrenciler bunları okuyarak kendi tarih algılarını oluşturmalıdır (Boboc, 2012; Iggers, 2000; Southgate, 2012; Y1lmaz, 2013).

Postmodern tarih anlayışı yerelliğe ve yerel kültüre vurgu yapmaktadır. Bu anlayışa göre tarihi sadece devletler, padişahlar, krallar, savaş ve barışlar oluşturmamaktadır. Toplum ve toplumun yaşantıları tarihi algılamakta daha önemli yer tutmaktadır. Özellikle resmi tarihte yer almayan kişi, olay ve zümrelerin incelenmesi gerektiğine vurgu yapılarak, tarihi, toplumları oluşturan insanların yaşadığı olayların meydana getirdiği savunulmaktadır. $\mathrm{Bu}$ nedenle postmodern tarih anlayışında yerel tarih ve sözlü tarih çalışmaları önem kazanmaktadır. Postmodern anlayışa göre öğrenciler, içinde bulundukları toplumu daha iyi anlamaları için yerel tarih çalışmaları yapmalıdırlar. Yerel tarihin incelenmesinin en uygun yaklaşımlardan birisi ise sözlü tarihtir. Öğrenciler bu çalışmalarla mikro tarihi inceleyebilecek ve ötekileştirildikleri için resmi tarih kitaplarına girmeyen kişi ve grupların incelenme firsatı bulacaklarıdır (Boboc, 2012; Iggers, 2000; Pamuk \&Şimşek, 2014; Y1lmaz, 2013).

Postmodern kuramın tarih eğitimi üzerindeki yansımaları incelendiği zaman, postmodernizmin tarih eğitiminde genellemelere değil spesifikliğe vurgu yaptığ gözlenmektedir. Bu bağlamda postmodern tarih anlayışında makro tarih değil, mikro tarih öğretilmelidir. Bunun yapılabilmesi içinse postmodern kuramın ön gördüğü en önemli yaklaşım yerel tarih ve yerel tarihin araştırılmasına en uygun yaklaşım olan sözlü tarihtir. $\mathrm{Bu}$ nedenle araştırma Postmodern kuram çerçevesinde yerel ve sözlü tarih yaklaşımları kavramsal çerçevesi doğrultusunda şekillendirilmiştir. Postmodern kuramın tarih eğitimi için ön gördüğü yerel tarih ve sözlü tarihi daha iyi anlamlandırabilmek için bu kavramları daha geniş açıklamak gerekmektedir.

\subsection{Yerel Tarih:}

Yerel tarih tarihin insanı ilgilendiren her alanı araştırması olarak tanımlanabilir. Konusu bir mahalle, köy, sokak, çeşme, köprü, aile, birey vb olan her şeyin araştırılması yerel tarihtir. Yöresel tarih, bölgesel tarih, (local history), mikro tarih kavramlarıyla karşımıza çıkan yerel tarih, yanı başımızda duran, topluma ait olan, toplumun kendine özgü kültürünün ve özelliklerinin araştırıldığı tarihe denir. Kısacası yerel tarih, merkezinde insan olduğu için tarihin bir kişi ya da vücuda bürünmesidir (Aslan, 2012; Caunce, 2001; Demircioğlu, 2010; Işık, 2008; Iş1k, 2014; Thompson, 1999; Tosh, 2005).

Yerel tarihin en önemli tezi, tarihin sadece şahsiyetlerin, kişi veya bireylerin, savaşların ve barışların, askeri ve siyasi tarihi olmadığı, bunların ötesinde, tarihi toplumsal, kültürel, ve ekonominin şekillendirdiği yaklaşımıdır. Tarihte yerellik, yaşanılan çevre ile ilgili her türlü özelliği içerir. Yerel tarihin ilgi alanı özel, spesifik ve mikro olsa da, aslında bakıldığı zaman bu durum genel tarihi de etkilemektedir (Aktekin, 2010; Işık, 2008; Thompson, 1999; Tosh, 2005).

Yerel tarihin konusu insanı ve toplumu ilgilendiren her şey labilmektedir. Yerel tarihi araştırmak toplumların daha iyi anlaşılmasına neden olacaktır. Yerel tarih çalışmalarına 16. 
yy'dan itibaren rastlanmasına rağmen yerel tarih çalışmalarının önemi 20.yy'ın ikinci yarısından itibaren artış göstermeye başlamıştır. Özellikle II. Dünya Savaşı'nın bütün dünyada yarattığı yıkım, tarih boyutunda önemli değişikliklere neden olmuş ve tarihin konusunun sadece savaş-barış tarihlerinden ibaret olmadığı, toplum hayatının gündelik yaşamın ve yöre tarihinin de araştırlmasını gündeme getirmiştir (Demircioğlu, 2010).

Yerel tarih, yakın çevre ile ilgilendiği için, yaşanılan çevredeki bulunabilecek pek çok şey, yerel tarihin ve öğretiminin konusu olabilmektedir. Bu bağlamda yerel tarihin konuları; haritalar, gazeteler, dergiler, hatıratlar, resimler, aileler, kişiler, soyadları, isimler ( köy, kasaba, şehir, bölge, sokak, cadde), binalar, okullar, evler, camiler, çeşmeler, hanlar, hamamalar, yollar, kervansaraylar, saraylar, tablolar, gravürler, mezarlar, mezar taşları, arkeolojik kalıntılar vb.'dir. Tarih derslerindeki en önemli eksikliklerden birisi de öğrencilerin tarih derslerine olan ilgisizliğidir denilebilir. Yerel tarih öğrencilerin ders ile bağ kurmalarını ve tarih dersine karşı olan ilgilerini artırmalarını sağlar. Yanıbaşındaki tarihi inceleyen öğrencinin buna paralel olarak derse bağlanması ve tarih derlerindeki başarıyı artırması düşünülmektedir (; Aslan, 2012; Counce, 2001; Demircioğlu, 2010; Iggers, 2000; Iş1k, 2014).

Yerel tarih günlük yaşamla birleşmeyi, toplumu ve çevremizi anlamamızı sağlar. Yerel tarih çalışmalarını okul dışında ve sınıf dışında yürütmek, öğrencinin sosyal hayatını, iletişim becerilerini geliştirmeyi ve dış dünya ile bağ kurabilmesini sağlamaktadır. Yerel tarih çalışmalarının avantajları dışında bazı dezavantajları da vardır. Öncelikle yerel tarih çalışmalarında karşılaşılabilecek en önemli problemlerden bir zaman problemidir. Çoğu zaman öğretmenler müfredatı yetiştirme kaygısıyla yerel tarih çalışmalarına çok fazla yer vermemektedirler. Sınıf dışında öğrenmenin gerçekleşmesi için zamanın yeterli olması gereklidir. Yerel tarih uygulaması yapılırken zaman sıkıntısı çekilebilir (Metin ve Oran, 2014).

Yerel tarih çalışmalarına günümüzde tarih araştırmalarında ve öğretiminde sıkça rastlanmaktadır. Yerel tarih çalışmaları özellikle tarih araştırmalarında ve öğretiminde yeni trendler arasına girmiştir. Yerel tarihin ana temasını insan oluşturduğu için, yerel tarihin araştırlmasında en önemli yaklaşım olarak günümüzde sözlü tarih kullanılmaktadır. $\mathrm{Bu}$ bağlamda sözlü tarih kavramının da açıklanması gerekmektedir.

\subsection{Sözlü Tarih:}

Geçmişe ait sözlü kanıt ve delillerin kayıt ve analizi olarak kabul edilen sözlü tarih, yaşayan bireylerin hafizalarındaki geçmişlerinin görüşme yoluyla kayda geçirilmesi ve analiz edilmesidir. Sözlü tarih insanlar arasında kurulmuş bir tarih türüdür. Sözlü tarih kahramanlarını sadece tanınmış kişiler arasından değil, o güne dek tanınmayan insanlar arasından seçmektedir. Bu yönüyle resmi tarihin ele almadığ 1 , kısaca ötekileştirilmiş kişiler arasından seçmekte ve sessiz insanların sesi olarak karşımıza çıkmaktadır (Counce, 2001; Iggers, 2000; Thompson, 1999; Tosh, 2005; Sar1, 2014).

Sözlü tarihin en önemli özeliklerinden biri, kültürün ve bireyin duygu ve düşüncelerine ulaşabilecek tarzda esnek olmasıdır. Bu açıdan düşünüldüğünde sözlü tarih kültürel ve 
toplumsal unsurların birbiriyle iç içe geçmesinin birey üzerindeki yansımalarını göstermektedir. Yani makro boyuttaki olayların, mikro boyutta nasıl yansıdığına 1şık tutmaktadır (Counce, 2001; Sağlam, 2010; Sarı; 2014).

Sözlü tarih, aslında tarih kadar eskidir. Var olan ilk tarih türü sözlü tarihtir. İnsanların ortaya çıkmasıyla sözlü tarihte ortaya çıkmıştır. İnsanların birbirlerine anlattıkları ve nesiller boyu devam eden anektotlar, efsaneler, destanlar hepsi birer sözlü tarih ürünüdür. Bunun dışında Antik Yunan tarihinde İliyada destanı yazıya geçirilmeden sözlü tarih olarak 6 yüzyıl boyunca korunduğu söylenmektedir. İlk tarihçiler olarak bilinen Heradot ve Thukydides'in de yazdıklarının önemli bir kısmı sözlü tarihe dayanmaktadır. Heradot, Pers savaşları, Thukydides'te Peleponnesos savaşları ile ilgili eserlerini sözlü olarak araştırıp yazmışlardır. Fakat yazının bulunması ile sözlü tarih önemini kaybetmiş ve tarihçiler arşiv belgelerine dayanarak, yazılı kaynaklar kullanarak tarih yazmaya başlamışlardır. Sözlü tarih çalışmalarının tekrar gündeme gelmesi ve popüler olması ise özellikle II. Dünya Savaşı sonrasında 20. yy'a rastlamaktadır. Teknolojinin ilerlemesine paralel olarak ve insan ses kayıt cihazlarının ortaya çıkması, sözlü tarihin daha kolay araştırılmasına ve yaygınlaşmasına neden olmuştur (Demircioğlu, 2010; Sarı, 2007; Sarı, 2014; Thompson, 1999).

Sözlü tarih, sosyal, kültürel ve halkçı bir söylemdir. Bunun nedeni sözlü tarihin insanı merkeze almasıdır. Sözlü tarih çalışmaları insanların belleklerinde bulunan hatıratlarla ilgilendiği için, insan sözlü tarihin ana malzemesidir. Sözlü tarih sayesinde devletler, makro anlatılar yerine, toplumun mikro anlatılarıyla, kendi toplumunu daha iyi tanıyabilmekte, ekonomik, sosyal, askeri, siyasi olayların topluma nasıl yansıdı̆̆ını öğrenebilmektedir (Counce, 2001; Sar1, 2007; Tosh, 2005).

Sözlü tarih, tarihçilerin geçmişi araştırırken kullandıkları bir yöntemdir. Sözlü tarih insanların hafızalarındaki olayların dinlenmesi ile insan belleğini kullanarak tarih yazılması metodudur. Bu yönüyle sözlü tarih bireysel ve toplumsal tarihlerin oluşturulumasında katkıda bulunur. Sözlü tarih, tarihin içine yaşamı, gündelik yaşamı sokmakta ve böylece yerel tarihin de araştırılmasını kolaylaştırmaktadır. $\mathrm{Bu}$ nedenle yerel tarihin araştırılmasında en uygun yöntem sözlü tarihtir. Sözlü tarih bir disiplinden çok bilimsel metod olarak karşımıza çıkar (Demircioğlu, 2010; Sarı, 2014; Thompson, 1999).

Sözlü tarih yönteminin yerel tarih uygulamalarında ve tarih eğitiminde kullanılması öğrenciye, dinleme, gözlem, soru sorma, kendilerinden önceki kuşakları anlama, organizasyon becerileri, yaparak yaşayarak öğrenme becerileri, ortak çalışabilme, sosyal ve kişilik becerileri, karşılaştırma yapabilme becerileri, konsantrasyonu artırma, verileri analiz etme ve yorumlama araştırma, eleştirel düşünme gibi beceriler kazandırılır (Demircioğlu, 2010; Sarı, 2007, Şahin, 2011).

\subsection{Yerel Tarih ve Sözlü Tarihin Tarih Eğitiminde Kullanılması:}

Okullarda tarih eğitiminde özellikle son zamanlarda yerel ve sözlü tarih etkinliklerinin düzenlenmesi popüler hale gelmiştir. Yerel tarih için yapılan en yaygın uygulamalar ise, okulun bulunduğu yörede yer alan yerel-tarihi binalara, yapıtlara veya müzelere yapılan 
geziler, bölge insanlarıyla ve yaşlılarla yapılan sözlü tarih çalışmaları, tarihi resimlerin ve slaytların sunumu ve analiz edilmesidir (Aktekin, 2010; Counce, 2001).

Yerel tarih çalışmalarında öğrenciler daha aktif olmaktadırlar. Tarih dersi sadece konuşma ve anlatıdan çıkıp, öğrencilerin yaparak ve yaşayarak öğrenmelerini sağlayacak bir yönteme dönüşmektedir. Yerel tarih çalışmalarında öğrenciler saha ziyaretleri yapabilmekte, bölgede bulunan yaşlı ve büyüklerle görüşme imkanı bulabilmekte yaparak-yaşayarak hem eğlenecek hem de öğrenecektirler. $\mathrm{Bu}$ da öğrencilerin tarihin öğrenilmesinde ve araştırılmasında aktif rol oynamalarını sağlamaktadır. Böylece öğrenciler kendi yaşantıları yoluyla tarihi öğrenmekte, tarih dersinin sıkıcı ve ezberci anlayışından uzaklaşmaktadırlar. Ayrıca tarih dersinin sadece tarih kitaplarıyla ve sınıf ortamıla sınırlı olmadığını kavrayabilmektedirler (Aktekin, 2010; Counce, 2001; Demircioğlu, 2010; Iggers, 2000; Thompson, 1999).

Yerel tarih çalışmaları öğrencilere deneyim kazandırmak, tarihi analiz etme, yorumlama ve rapor etme becerileri kazandıracaktır. Ayrıca öğrencilerin yapacakları yerel tarih çalışmaları öğrencilere; tarih derslerindeki bazı soyut kavramları da daha iyi anlamalarına neden olacaktır. Yerel tarih çalışmaları ayrıca öğrencilerin tarih bilincinin gelişmesinde, yaparak yaşayarak öğrenme imkanı sağlamada, birinci elden deneyim ve keşif imkanı sağlamada, tarih dersini daha eğlenceli bulmada, tarihsel kalıntıları koruma bilinci geliştirmekte, yaşanılan çevreyi daha iyi tanımada, merak duygularını geliştirmede, dün, bugün ve gelecek arasında ilişki kurabilme imkanı sağlayacaktır. Bu açıdan yerel tarih çalışmaları tarih eğitiminde önemli bir yere sahiptir (Aktekin, 2010; Demircioğlu, 2010; Thompson,1999).

Yerel tarihin en popüler uygulama şekli gezi, gözlem ve sözlü tarih yöntemleridir. Öğrenciler gezi ve gözlem yöntemiyle çevrelerindeki tarihi tanıyarak öğrenerek, sözlü tarih yöntemi ile de bölgedeki insanlardan da bilgi edinebileceklerdir. Sınıf dışındaki yerel tarih çalışmaları öğrencilerin diğer derslerle de bağ kurmalarına neden olmaktadır. Öğrenciler yerel tarih ile saha çalışması yaptıklarından dolayı, sanat, ekonomi, coğrafya ve çevre çalışmaları gibi konularında farkındalık kazanabilmektedirler (Aktekin, 2010).

Yerel tarihin uygulanmasında en uygun ve popüler yöntemin sözlü tarih çalışmaları olduğundan daha de önce bahsedilmiştir. Sözlü tarih çalışmaları bireysel olabileceği gibi grup çalışması olarak da uygulanabilmektedir. Ortak yapılan sözlü tarih uygulamaları, rekabet ortamı yerine dayanışmayı sağlar, öğretmen ve öğrenciler arasındaki ilişkiyi daha az hiyerarşik bir yapıya sokar. Böylece öğrenciler gerek bireysel, gerekse grup çalışmaları ile

sözlü tarih uygulamalarına katıldıkları zaman işbirliğine dayalı öğrenme gerçekleştirirler (Counce, 2001; Demircioğlu, 2010; Sarı, 2007; Şahin, 2011; Thompson, 1999).

\subsection{Türkiye'de yürütülen Tarih Eğitimi çalışmalarında postmodern, yerel ve sözlü tarih konularının ele alınışı:}


Postmodernizm, yerel tarih, sözlü tarih ve özellikle postmodernizmin tarih eğitimine katkıları veya etkileriyle ilgili olarak maalesef Türkiye'de Avrupa'da yapılanlar kadar çok çalışma bulunmamaktadır. Özellikle son zamanlarda Tarih eğiitminde yeni yaklaşımların da benimsenmesiyle yerel tarih ve sözlü tarih ayrı ayrı veya birlikte hem araştırma iyöntem hemde öğretim tekniği olarak kullanılmaya başlanmıştır. Spesifik olarak yerel tarih, sözlü tarih veya her ikisinin de kullanılarak yapıldığı çalışmalar olmasına rağmen postmodern yaklaşıma bu çalışmalarda yer verilmemiştir.

Türkiye'de yapılan çalışmalara bakıldığı zaman, yerel gtraih ve sözlü tarih ile ilgili pek çok kitap veya makaleye ulaşmamız mümkğndür. Ayrıca son yıllarda bu konu ile ilgili yapılan akademik tezlerde de artış gözlenmektedir.

Bunlardan bazılarına bakacak olursak, 2010 yılında Ankara Üniversitesi, Güzel Sanatlar Eğitimi Programı bünyesinde doktora tezi olarak yapılan, Postmodern Sanat Eğitimi Kapsamında İlköğretim Görsel Sanatlar Eğitiminin Değerlendirilmesi ve Programın Yeniden Yapılandırılması İçin Öneriler” dir. Yapılan çalışmada yöntem olarak literatür taranmış ve döküman analizi yapılmıştır. $\mathrm{Bu}$ bağlamda postmodernizmin sanat eğitimi programlarına yansımaları ele alınmış, mevcut program değerlendirilerek, programın postmodern kurama göre yeniden yapılandırılması için öneriler geliştirilmiştir.

2007 yılında Gazi Üniversitesi Sosyal Bilgiler Öğretmenliği Bilim Dalı bünyesinde, "Sosyal Bilgiler Öğretiminde Sözlü Tarih Etkinliklerinin Öğrenci Başarı, Beceri ve Tutumlarına Etkisi”" adlı doktora çalışması alandaki önemli bir diğer çalışmadır. Araştırmada nitel ve nicel veriler birlikte kullanılarak karma yöntem izlenmiştir. Araştırmanın nicel boyutunda deneysel çalışılmıştır. Araştırmada deney ve kontrol grubu oluşturularak, ilköğretim 7. Sınıfların 7A ve 7B sınıflarından 23'er öğrenci çalışmaya dahil edilmiştir. Öğrencilere araştırmacı tarafından hazırlanan görüşme soru yaprağı verilmiştir. Bu sorular ders kapsamında sözlü tarih olarak görüşmeci olarak sınıfa getirilen şahsa öğrenciler tarafından uygulatılmıştır. Ayrıca öğrencilere 25 sorudan oluşan başarı testi uygulanmıştır. Araştırmanın nitel boyutunda ise öğrencilere dersle ilgili deneyimlerini içeren bir kompozisyon yazmaları istenmiş ve bu kompozisyonlar döküman analizi ile incelenmiştir. Araştırmacı bü yöntemlerin hepsinden elde ettiği verileri çözümleyerek bulgulara ulşaşmıştır. Elde edilen bulgular 1şı̆̆ında sözlü tarihin ilköğretim sosyal bilgiler dersi kapsamında uygulatılması öğrenci başarısını arttırmıştır.

2012 yılında yapılan bir diğer araştırma ise Marmara Üniversitesi Eğitim Bilimleri Enstütüsü, Ortaöğretim Sosyal alanlar Eğitimi Anabilim Dali, Tarih Öğretmenliği Bilim Dalı bünyesinde bir doktora tezidir. Yerel ve Sözlü Tarih algısının Ortaöğretim Öğrencileri Üzerindeki Yansımaları (Tunceli Merkez Örneği) ni araştıran araştırmacı, nitel araştırma yöntemi kullanmıştır. Araştırmacı evren olarak Tunceli kent merkezinde bulunan 10 ortaöğretim okulunun 12. Sinıfında okuyan 482 öğrenci ve 12 tarih öğretmeni olarak belirlemiş, bu evren içerisinden 8 ortaöğretim okulundan 142 öğrenci ve 6 tarih öğretmeni ile çalışmıştır. Araştırmacı, örneklem grubunu seçerken Tuncelili Alevi olma ve Tunceli merkezli olma kriterlerini dikkate almıştır. Seçilen örneklem grubu ile, sekiz lisenin birer 
şubesinden beşer öğrenci yani toplamda kırk öğrenci ile yarı yapılandırılmış mülakat yapılmış, dokuz öğrenci ile odak grup çalışması, son olarak açık uçlu soru formu için 3 liseden 108 öğrenci ile çalışılmıştır. Altı tarih öğretmeni ile de mülakat yapıllmıştır. Toplanan veriler, içerik analizi, betimsel analiz ve verilerin tasnifi yöntemleri ile analiz edilerek bulgulara ulaşılmıştır. Bu bağlamda ulaşılan bulgulara göre resmi tarih öğretimde anlatılan tarihi bilgiler ile alevi öğrencilerin aileleri tarfından aktarılan tarihi bilgilerin alevi öğrencilerin tarih algısında karmaşa ve kaos yarattığına varılmıştır. Ayrıca, resmi tarihte yer almayan alevi tarihi nedeniyle, alevi öğrencilerin resmi tarihe inanma duygularının zayıflığı saptanmıştır.

\section{Sonuç}

Postmodernizm, her alana etki ettiği gibi tarih alanını da etkilemiştir. Postmodernizmin tarih ve tarih eğitimine yansıması da kendi doğası gereği geleneksel tarih anlayışı dışında farklı bir boyutta olmuştur. Bu yansıma tarihin gelenekselci yapısına aykırı olmakla birlikte tarih ve tarih eğitimine yeni bir bakış açısı getirmiştir. Buradan hareketle postmodernizmin tarih eğitimi için yenilikçi bir bakış açısı getirdiğini söylemek yanlış olmaz. $\mathrm{Bu}$ yaklaşıma göre tarih eğitiminde tarih yazıcılığında günlük olaylar önem kazanmaktadır. Yani tarihin konusu sadece savaş, barış, devletler tarihi, siyaset vs. değil gündelik hayat, yaşadığımız her an olmalıdır. Bu noktada postmodern yaklaşım temelli tarih eğitimi için en uygun yöntemler yerel ve sözlü tarih olmalıdır.

Yerel tarih yaşadığımız bölgenin tarihi, mahalli tarih olarak da olarak geçmektedir. Yerel tarihin konusu insanın yaşadığı çevredeki her şey olabilir. Sokaklar, yollar, kaleler, köy, kasaba, gazete ve dergi gibi birçok şey. Yerel tarih yaşanılan coğrafyadaki her şeyi inceleyebilir. Yerel tarihi en iyi inceleyebileceğimiz yol ise o bölgedeki yaşayan insanlardan bilgiler almaktır. Bu noktada devreye sözlü tarih girmektedir.

Sözlü tarih insan odaklı bir araştırma yöntemi olmakla birlikte, toplumsal sınıflar ve kuşaklar arasında bağlantı kuran gündeliği, öznelliği, sıradan bireyi tarihin araştırma alanına dahil eden ve ses kaydetme teknolojilerinin de kullanılmasıyla geliştirilen disiplinler arası bir çalışma alanıdır.

Tarih eğitiminde postmodern yaklaşım temelli olarak yerel tarih ve sözlü tarih uygulamalarının kullanılması öğrencilerin yaparak yaşayarak ve kalıcı öğrenmelerine yol açacaktır. Ayrıca öğrenciler ezbere dayalı değil, kendi deneyimleri yoluyla tarihi öğrenebilecekler ve tarih dersini daha çok sevebileceklerdir. Bu yöntemlerin tarih eğitiminde kullanılması öğrencilerde araştırma becerileri geliştirme, soru sorma, gezi-gözlem yapma, sorgulama, düşünme gibi becerilerde geliştireceğinden kalıcı öğrenmelere yol açacaktır.

Sonuç olarak öğrenciler yerel ve sözlü tarih uygulamaları ile kişisel gelişimlerini, tarihi anlama ve algılama becerilerini geliştirirler. Tarih eğitiminin eğlenceli olduğu kanısına varırlar. Tarihi öğrenmede bireysel kazanımlar ve tecrübeler elde ederek, eleştirme ve yorumlama becerisi kazanabilirler. 


\section{Öneriler:}

$\checkmark$ Postmodern ĕ̌itim anlayışı birçok anabilim dalı programında her alanda uygulanabilmelidir.

$\checkmark$ Postmodern tarih anlayışı tarih öğretim programlarına adapte edilmesi için çalışmaların özendirilmesi yararlı olabilir.

$\checkmark$ Özellikle yerel ve sözlü tarih tarih eğitim programlarına entegre edilmesi faydalı olabilir.

$\checkmark$ Tarih eğitiminde ögrencilere tarih bilincinin kazandırabilmesi ve daha aktif olabilmeleri için yerel tarih ve sözlü tarih yaklaşımlarının daha fazla kullanılabilmelidir.

$\checkmark$ Tarih ders kitaplarında yerel tarih ve sözlü tarih etkinliklerine yer verilebilir.

$\checkmark$ Öğrenciler yerel tarih ve sözlü tarih çalışmaları için teşvik edilmelidir.

$\checkmark$ Postmodernizin tarih ĕgitiminde kullanılması ile ilgili daha çok araştırma yapılması bu alanda çalışanlar için daha çok verimli olacaktır.

$\checkmark \quad$ Yerel tarih ve sözlü tarih ile ilgili daha çok araştırma yapılmalıdır.

\section{Kaynakça:}

Arslan, Y. (2012). Yerel ve sözlü tarih algısının ortaöğretim öğrencileri üzerindeki yansımaları (Tunceli merkez örneği). Yayımlanmamış Doktora Tezi.

Akpınar, B., Çakmak, Z., \& Kara, C. (2010). Postmodernizmin ilköğretim 6. ve 7. Sinıf sosyal bilgiler öğretim programına yansımaları., Fırat Üniversitesi Sosyal Bilimler Dergisi, 20 (2) $137-160$.

Aksoy, N. (2010). Postmodern sanat eğitimi kapsamında ilköğretim görsel sanatlar eğitiminin değerlendirilmesi ve programın yeniden yapılandırlması için öneriler, Yayımlanmamış Doktora Tezi., Eğitim Bilimleri Enstitüsü, Ankara Üniversitesi.

AKTEKİN, S. (2010). Ortaöğretim tarih eğitiminde yerel tarihin yeri ve önemi., Eğitimde Kuram ve Uygulama, 6(1), 86-105.

Aydın, H. (2006). Eğitimde modern ve postmodern modeller., Bilim ve Gelecek Dergisi, 33, 60-69.

Boboc, M. (2012). The postmodern curriculum in a modern classroom. International Journal of Education, 4(1), 142.

Caunce, S. (2001). Sözlü tarih ve yerel tarihçi., (çev: B. Bülent Can, Alper Yalçınkaya), İstanbul: Tarih Vakfi Yurt Yayınları.

Coleman, M. C. (2013). Response to a postmodernist: Or, a historian's critique of postmodernist critiques of history., At the Limits of History (pp. 129-142). Routledge.

Demircioğlu, İ. (2010). Tarih öğretiminde öğrenci merkezli yaklaşımlar., tarih bölümü özel öğretim yöntemleri., (3. Baskı), Ankara: Anı Yayıncılık. 
Doltaş, D. (2003). Postmodernizm ve eleştirisi, tartışmalar, uygulamalar., Ankara: İnkılap Yayınlar1.

Hart, S. (2007). Derrida and postmodernity: at the end(s) of history., requirement for a higher degree of the university of southampton.

Harvey, D. (2003). Postmodernliğin durumu., (çev: Sungur Savran), İstanbul: Metis Yayınlar1.

Hollinger, R. (2005). Postmodernizm ve sosyal bilimler, tematik bir yaklaşım., (çev. Ahmet Cevizci), İstanbul: Parardigma Yayınları.

Iggers, G. G. (2000). Bilimsel nesnellikten postmodernizme, yirminci yüzyılda tarih yazımı., (çev: Gül Çağalı Güven)., (2. Baskı), İstanbul: Tarih Vakfı Yurt Yayınları.

Işık, H. (2008). İlköğretimde tarih konularının yerel tarih ile ilişkilendirimesinin öğrenci başarısına etkisi., Uluslararası Sosyal Araştırmalar Dergisi, I/4(291-310)

Işık, H. (2014). Tarih öğretimi ve yerel tarih., M. Safran (Ed.) Tarih Nasıl Öğretilir? Tarih Ögretmenleri İçin Özel Öğretim Yöntemleri., (2. Bask1), (ss.256-266), İstanbul: Yeni İnsan Yayınevi.

Jencks, C. (2010). What is Postmodernism? John Wiley \& Sons Ltd.

Jenkins, K. (1997). Tarihi Yeniden Düşünmek, (çev: Bahadır Sina Şener), Ankara: Dost Kitabevi Yayınları.

Keskin, A. (2008). Post-Modern dünyada modern tarih yapmak üzerine., U. Ü. Fen-Edebiyat Fakültesi Sosyal Bilimler Dergisi, 9,15.

Kılıç, L. \& Bayram, B. (2014), Postmodernizm ve eğitim., Uluslararası Türkçe Edebiyat Kültür Eğitim Dergisi,3/1, 368-376.

Koruroğlu, A., \& Özkul, A. E. (2017). An evaluation of local and oral history of Cyprus teaching on the basis of postmodern education: student and teacher opinions. Eurasia Journal of Mathematics, Science and Technology Education, 13(11), 7295-7306.

Lyotard, J. F. (2000). Postmodern durum., (çev: Ahmet Çiğdem), Ankara: Vadi Yayınları.

Metin, B., \& Oran, M. (2014). İlköğretim sosyal bilgiler öğretmenlerinin ders içi yerel tarih konusundaki faaliyetleri Uşak ili örneği., Uşak Üniversitesi Sosyal Bilimler Dergisi, 7(1), 204-216.

Opperman, S. (2006). Postmodern tarih kuramı, tarih yazımı, yeni tarihselcilik ve roman., Ankara: Phoenix Yayınları.

Parkers, R. J. L. (2006). Interrrupting history a critical-reconceptualisation of history curriculum after 'the end of history'., Submitted in fulfilment of the requirements for the degree of Doctor of Philosophy, School of Education, University of Newcastle.

Sağlam, M. (2010). 1970-1975 dönemi ilkokul öğrencilerinin eğitim deneyimleri, sözlü tarih yöntemiyle bir çalışma., Yayımlanmamış Doktora Tezi, Eğitim Bilimleri Enstitüsü, Ankara Üniversitesi.

Sarı, İ. (2007). Sosyal bilgiler öğretiminde sözlü tarih etkinliklerinin öğrenci, başarı, beceri ve tutumlarına etkisi., Yayımlanmamış Doktora Tezi, Eğitim Bilimleri Enstitüsü, Gazi Üniversitesi. 
Sarı, H. (2014). Tarih öğretimi ve sözlü tarih., M. Safran (Ed.) Tarih nasıl öğretilir? Tarih öğretmenleri için özel öğretim yöntemleri, (2. Bask1), (ss.251-255), İstanbul: Yeni İnsan Yayınevi.

Sarup, M. (2004). Post-yapısalcılık ve postmodernizm., (çev: Abdülbaki Güçlü), (2. Baskı), Ankara Bilim ve Sanat Yayınları.

Southgate, B. (2012). Tarih:ne ve neden, antik, modern ve postmodern yaklaşımlar., (çev: Çağdaş Dizdar, Erhan Baltacı, Didem Salihoğlu, Tuba Altın, Berkay Ekrem Ersöz), Ankara: Phoenix Yayınları.

Şahin, C. T. (2011). Yerel tarih uygulamalarının başarıya ve öğrenci ürünlerine etkisi., Uluslararası Sosyal Araştırmalar Dergisi, 4, 16. 453-462.

Şimşek, A. \& Pamuk, A. (2014). Tarih Yazıcılığının Dünü, Bugünü ve Yarını Üzerine Kısa Bir Bakış, M. Safran (ed.) Tarih Nasıl Öğretilir? Tarih Öğretmenleri İçin Özel Öğretim Yöntemleri, (2. Bask1), (ss.23-28), İstanbul: Yeni İnsan Yayınevi.

Thompson, P. (1999). Geçmişin sesi., (çev: Şehnaz Layıkel), İstanbul: Tarih Vakfı Yurt Yayınlar1.

Tosh, J. (2005). Tarihin peşinde., (çev: Özden Arıkan), (2. Baskı), İstanbul: Tarih Vakfı Yayınları.

Yılmaz, K. (2013). Postmodernist yarih yaklaşımı: postmodernizmin tarih eğitimi için doğurguları., Pamukkale Üniversitesi Eğitim Fakültesi Dergisi, 34, 197-209. 